\title{
PELATIHAN PENGGUNAAN VIDEO CONFERENCE MENGGUNAKAN GOOGLE MEET UNTUK SISWA DI DESA PAGERAGUNG KECAMATAN WALANTAKA KABUPATEN SERANG
}

\author{
Firdaus \\ Universitas Banten Jaya, Jl Syech Nawawi Albantani Serang, Banten, Indonesia \\ Email: dauzkd6ptr@gmail.com
}

\begin{abstract}
ABSTRACK
This training activity on the use of video conferencing using Google Meet aims to introduce interactive online learning media to students. The choice of video conference in the form of Google Meet is because this application is very light in terms of storage capacity and all features can be used for free. The method used is in the form of workshops that are carried out offline while still complying with the covid 19 health protocol. Steps start from preparation in students and training locations and implementation is carried out starting from guiding the installation process of the google meet application to introducing the available features. The training carried out received a good response from students because after the training they felt that the Google Meet application could later be used not only for learning but also to stay in touch with friends and family.
\end{abstract}

Keywords: Training; Video Conferencing; Google Meet; Students

\begin{abstract}
ABSTRAK
Kegiatan pelatihan penggunaan video conference menggunakan google meet ini bertujuan untuk memperkenalkan media pembelajaran secara daring yang interaktif kepada siswa. Pemilihan video conference berupa google meet dikarenakan aplikasi ini sangat ringan dari sisi kapasitas penyimpanan dan semua fitur bisa digunakan secara gratis. Metode yang digunakan berupa workshop yang dilakukan secara luring dengan tetap mematuhi protocol kesehatan covid 19. Langkah dimulai dari persiapan dalam siswa dan lokasi pelatihan dan pelaksanan dilaksanakan mulai dari membimbing proses instalasi aplikasi google meet sampai dengan memperkenalkan fitur yang tersedia. Pelatihan yang dilakukan medapat tanggapan yang baik dari siswa karena setelah pelatihan mereka merasa aplikasi aplikasi google meet nanti bisa digunakan bukan hanya untuk pembelajaran tapi juga untuk bersilaturahmi dengan teman dan keluarga.
\end{abstract}

Kata Kunci : Pelatihan; VideoCconference; Google Meet; Siswa

\section{PENDAHULUAN}

Pandemi corona virus disease 2019 (covid 19) pertama kali ditemukan pada akhir tahun 2019 di Kota Wuhan, Provinsi Hubei, China. Organisasi Kesehatan Dunia (WHO) yang berada di China memperoleh pemberitahuan tentang adanya sejenis penyakit yang mirip dengan Pneumonia, yaitu salah satu penyakit infeksi pernapasan akut yang menyerang paru-paru, akan tetapi penyebabnya belum diketahui secara pasti. Berdasarkan informasi dari pihak berwenang, pasien yang terinfeksi covid 19 merupakan pedagang yang bekerja di pasar ikan Huanan. 
Akibatnya, seluruh aktivitas sosial yang biasanya berjalan normal, menjadi terhenti. Sebagian besar perusahaan dan sarana pendidikan mulai beradaptasi dengan memperkerjakan karyawannya dari rumah (work from home) dan membuat sistem belajar online untuk siswa dan mahasiswa. Sebab adanya kemajuan teknologi pada masa sekarang ini seluruh kegiatan dapat dilaksanakan secara online. Ada berbagai macam media pembelajaran yang dapat menunjang atau membantu kegiatan bekerja dan belajar online.

Di tahun 2021 dunia masih menghadapi kondisi yang sulit di berbagai bidang terutama bidang pendidikan yaitu masih ada nya covid 19. Tentu sangat mengganggu keadaan dan kesehatan manusia, terutama berdampak pada aktivitas pendidikan. Pelaksanaan pendidikan yang semula di laksanakan secara langsung dan bertatap muka kini harus berganti. Kondisi demikian menuntut lembaga pendidikan untuk melakukan inovasi dalam proses pembelajaran. Salah satu bentuk inovasi tersebut ialah dengan melakukan pembelajaran secara online atau daring (Astini, 2020). Dimana pada masa pandemik ini pembelajaran dilakukan secara daring dengan berbagai teknologi informasi sebagai media pembelajaran seperti aplikasi zoom meeting, google classroom, dan sebagainya, hal ini tentu sangat membutuhkan sarana dan prasarana yang memadai, seperti Smartphone, laptop/komputer, ketersediaan kuota/wifi, jaringan internet, dan lainnya. Tetapi dengan kesulitan yang dihadapi tentu pelaksanaan pembelajaran akan tetap dilaksankan dengan baik, sehingga pengetahuan, ketrampilan dan kemampuan serta pola pikir siswa akan terus berkembang dan meningkat (Sugandi et al., 2020).

Perubahan media pembelajaran dari luring menjadi daring secara mendadak yang terjadi diawal pandemi covid-19 ini sangatlah menyulitkan peserta didik maupun pendidik karena belum ada kemampuan dalam menggunakan teknologi untuk pembelajaran secara daring. Namun setelah setahun lebih pandemi covid-19 ini berlalu, peserta didik maupun pendidik menjadi lebih handal dalam menggunakan teknologi pembelajaran secara daring. Tentu ada kekurangan ketika pembelajaran dilakukan secara daring, salahsatu yang sering dikeluhkan oleh peserta didik maupun pendidik adalah materi pembelajaran maupun perkuliahan yang di sampaikan kurang terserap dengan baik dibandingkan dengan pembelajaran yang dilakukan secara luring.

Salah satu instrumen dalam proses pembelajaran daring adalah media pembelajaran. Media pembelajaran sendiri merupakan perantara atau penghubunga antara sumber informasi dan penerima informasi (Tafonao, 2018). Media pembelajaran yang dilakukan secara daring oleh anak sekolah hanya sebatas WhatsApp massage dimana tidak terjadi interaksi secara sinkronus antara siswa dan guru yang mengakibatkan sangat minimnya materi pembelajaran yang diserap oleh siswa. Hasil observasi di lapangan, banyak sekali anak sekolah yang naik kelas tapi merasa tidak mendapatkan pengetahuan apapun. Oleh karena itu perlu adanya media pembelajaran secara daring yang memungkinkan terjadi interaksi antara siswa dan guru, Suatu media pembelajaran 
yang baik harus bersifat interaktif (Arianti, 2020). Media pembelajaran berupa video conference salahsatunya adalah google meet. Google meet di gunakan karena sangatlah ringan dari sisi kapasitas penyimpanan dan semua fitur bisa digunakan gratis, mengingat lebih banyak siswa yang menggunakan gadget entry level. Kemudian jenis gadget yang paling banyak dimiliki oleh siswa maupun keluarganya adalah handphone. Oleh karena itu, pengabdian ini lebih difokuskan kepada siswa sekolah yang mempunyai handphone dan aplikasi yang digunakan adalah google meet. Dengan banyak nya siswa yang menggunakan gadget entry level sehingga pembelajaran yang idealnya memiliki interaktifitas antara pendidik dan peserta didik walaupun tidak dalam satu tempat yang sama, dengan adanya video conference akan membantu proses pembelajaran yang dilakukan, karena pendidik akan terlibat langsung dengan peserta didik (Sandiwarno, 2016).

\section{METODE}

Metode yang digunakan dalam pelaksanaan pelatihan berupa workshop ini sebagai upaya untuk mencapai tujuan pengabdian, kegiatan pengabdian ini dilaksanakan secara luring dengan menerapkan protokol kesehatan covid 19. Adapun tahapan yang dilakukan adalah sebagai berikut:

1. Observasi cara pelatihan sebelum kegiatan dilaksanakan, untuk mencari metode pelatihan efisien bagi para peserta

2. Menganalisis materi pelatihan yang relevan untuk kemudian di urutkan langkah demi langkahnya

3. Persiapan yang terdiri dari kordinasi dengan pihak terkait

4. Pemilihan lokasi dan calon peserta pelatihan

5. Pelaksanaan pelatihan yang terdiri bagaimana instalasi aplikasi google meet, bagaimana cara menggunakan aplikasi google meet, fitur-fitur yang ada pada aplikasi google meet sehingga peserta dapat memahami mengenai penggunaan aplikasi google meet.

6. Bimbingan dan tanya jawab dimana selama kegiatan ini berlangsung selalu memberikan bimbingan dan jawaban kepada para peserta pelatihan secara langsung tentang berbagai pertanyaan yang berhubungan dengan Pemanfaatan google meet.

\section{HASIL DAN PEMBAHASAN}

\section{Persiapan}

1. Kordinasi mengenai kegiatan KKM yang dihadiri oleh dosen pembimbing lapangan, mahasiswa dan perangkat desa Pageragung. Tahap kordinasi ini akan disampaikan informasi mengenai beberapa program kerja yang akan dilaksanakan salahsatunya adalah pelatihan 
penggunaan video conference berupa google meet untuk siswa di desa Pageragung yang ditunjukan pada Gambar 1.

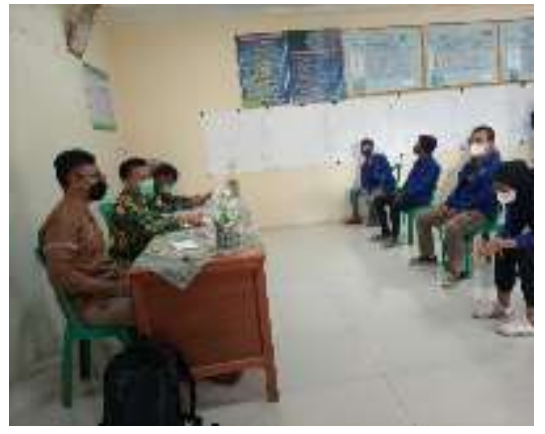

\section{Gambar 1. Kordinasi Kegiatan KKM}

2. Pada tahap ini mahasiswa melakukan pemilihan calon peserta pelatihan yaitu siswa sekolah yang sebelumnya sudah berkordinasi dengan RT setempat. Setelah mendapatkan calon peserta pelatihan kemudian mahasiswa melakukan kunjungan dan menjelaskan tentang kegiatan pelatihan yang akan dilaksanakan. Setelah itu berkordinasi lagi dengan pihak RT untuk menentukan tempat pelaksanaan pelatihan yang memadai.

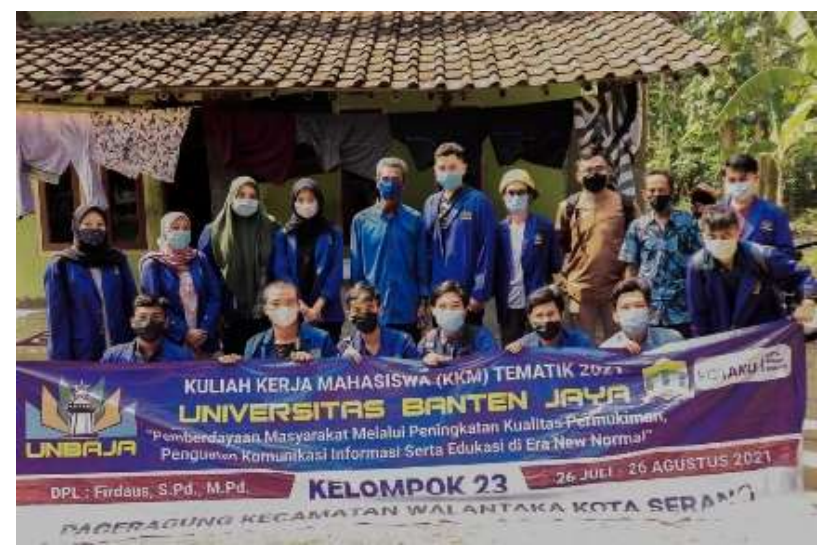

\section{Gambar 2. Lokasi Pelatihan KKM}

\section{PELAKSANAAN KEGIATAN}

Pelaksanaan Kegiatan Pelatihan ini dilakukan dengan menerapkan protokol kesehatan covid 19, yaitu mencuci tangan, menjaga jarak dan memakai masker. Pendampingan mengenai cara instalasi dan penggunaan aplikasi google meet dilakukan oleh mahasiswa dengan bimbingan dari dosen pembimbing lapangan kemudian juga dijelaskan tujuan dan manfaatnya yang ditunjukan pada Gambar 3. 


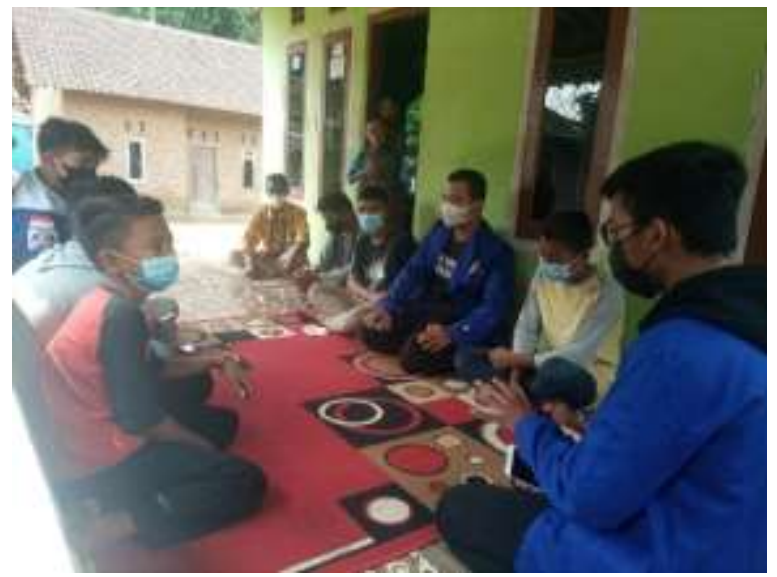

\section{Gambar 3. Pendampingan Penggunaan Aplikasi Google Meet}

Berikut ini langkah-langkah penggunaan aplikasi google meet yang dimulai dari cara instalasi aplikasi sampai dengan cara menggunakan google meet.

1. Buka aplikasi Play Store di hanphone, kemudian ketik google meet. Kemudian klik install. Tunggu sampai proses download selesai

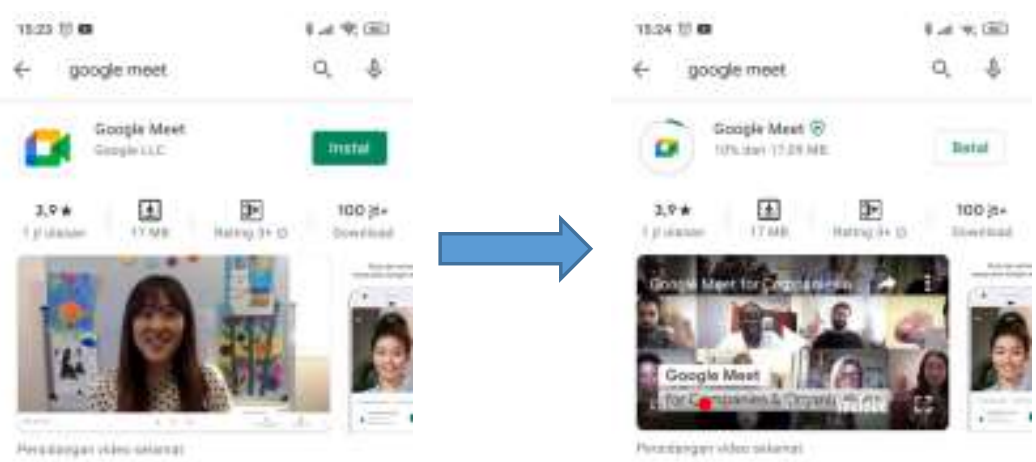

Gambar 4. Instalasi Google Meet

2. Setelah selesai instalasi kemduian klik buka. Kemudian akan masuk ke menu login. Masukan akun google mail yang dimiliki oleh siswa. Apabila tidak mempunyai google mail maka siswa dampingi bagaimana membuat akun google mail. 


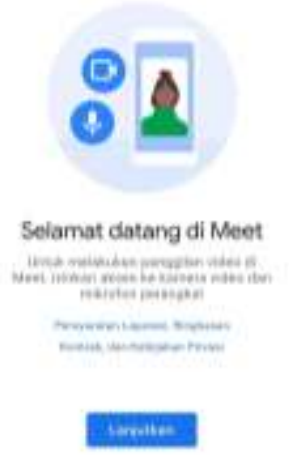

Gambar 5. Tampilan Google Meet

3. Setelah itu masuk ke halaman pembuka di aplikasi google meet. Klik lanjutkan. Setelah itu ada pemberitahuan untuk meminta ijin google meet mengambil gambar dan merekam video. Kemudian siswa dampingi untuk mengklik ijinkan. Setalah itu siswa masuk ke menu utama atau beranda dari aplikasi google meet.
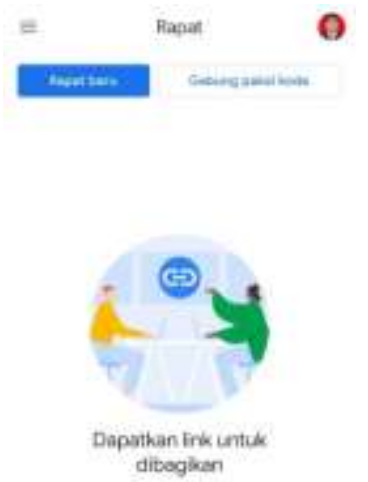

\section{Gambar 6. Menu Utama Google Meet}

4. Siswa sudah memasuki halaman utama google meet. Apabila siswa ingin membuat rapat baru atau melakukan video conference maka siswa diminta untuk mengklik rapat baru. Maka akan muncul link rapat yang bisa di bagikan.

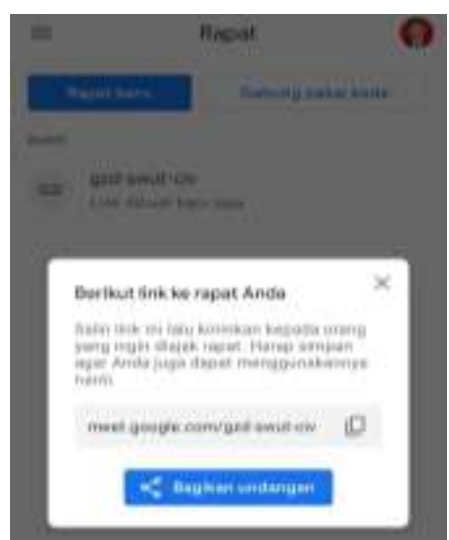

Gambar 7. Bagikan Link Google Meet 
5. Apabila siswa ingin mengundang temannya, keluarga ataupun guru untuk melakukan video conference maka siswa tinggal mengklik bagikan undangan dan mengirimkan link rapat ke WhatsApp massage atau media lainnya. Apabila sebaliknya siswa yang di undang temannya, keluarga ataupun gurunya untuk melakukan video conference maka siswa tinggal mengklik gabung menggunakan link rapat dan mengisinya dengan kode yang sudah dibagikan sebelumnya.

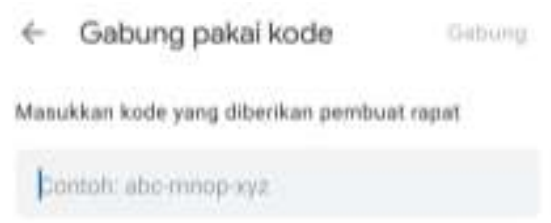

\section{Gambar 8. Bergabung Menggunakan Kode Google Meet}

6. Apabila siswa ingin memulai rapat secara langsung. Siswa diminta untuk mengklik rapat baru kemudian klik mulai rapat instan. Setelah itu siswa memasuki rapat yang didalamnya hanya siswa sendiri. Apabila siswa ingin mengundang orang lain bergabung maka siswa diminta untuk mengklik bagikan undangan lalu membagikannya ke media lainnya

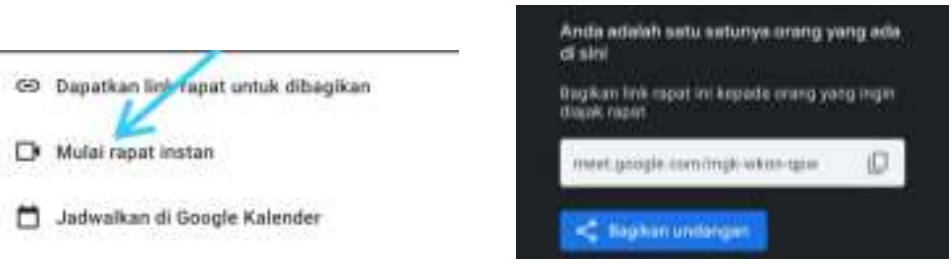

\section{Gambar 9. Rapat di Google Meet}

7. Apabila siswa ingin menjadwalkan kegiatan di google meet maka siswa diminta untuk menglik rapat baru kemudian klik jadwalkan di google calender. Tentu harus meninstal terlebih dahulu aplikasi google calendar. Setelah itu akan masuk ke aplikasi google calendar kemudian tinggal mengatur kapan akan melakukan rapat lagi. 


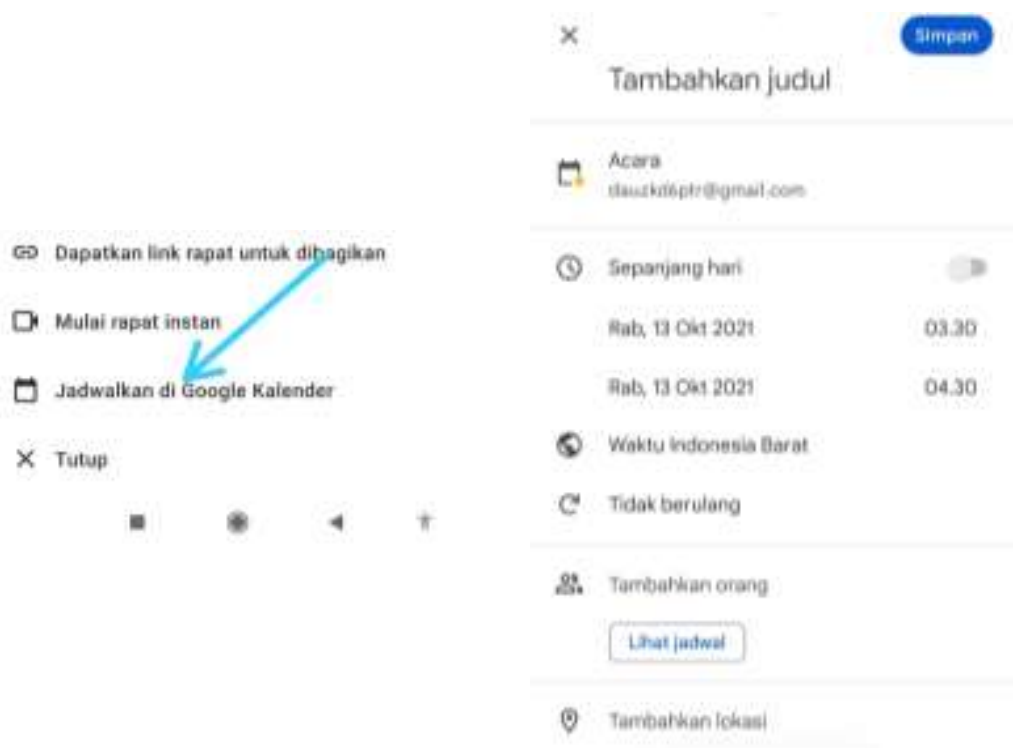

Gambar 10. Jadwal Google Calendar

\section{KESIMPULAN}

Kegiatan KKM yang dilakukan dengan dilaksanakan secara secara luring. Tujuannya agar siswa dapat memahami materi pelatihan dengan baik dan bisa mempraktikkannya secara langsung. langkah-langkah yang dilakukan pada kegiatan pelatihan ini adalah:

1. Menerapkan protokol kesehatan sebelum, ketika dan sesudah melakukan pelatihan. Dalam proses pelaksanaan pelatihan siswa dengan teratur mengikuti protokol kesehatan yang sudah dibuat oleh panitia pelaksana.

2. Menjelaskan apa itu pembelajaran daring dan manfaatnya. Pada bagian ini mahasiswa menyampaikan tentang berbagai media daring yang dipergunakan dalam pembelajaran termasuk google meet. Dari penjelasan yang disampaikan para peserta telah memahami kekurangan dan kelebihan dari masing-masing aplikasi pembelajaran yang dijelaskan.

3. Menjelaskan tentang google meet beserta cara penggunaannya. Kemudian mempraktikan pengunaan google meet.

4. Faktor pendukung yang dalam pelatihan ini adalah antusiasme siswa yang sangat tinggi sedangkan faktor penghambat berupa koneksi internet yang tidak stabil di desa Pageragung.

5. Pelatihan yang dilakukan mendapat tanggapan yang baik dari siswa karena setelah pelatihan mereka merasa aplikasi aplikasi google meet nanti bisa digunakan bukan hanya untuk pembelajaran tapi juga untuk bersilaturahmi dengan teman dan keluarga. 


\section{DAFTAR PUSTAKA}

Arianti, B. D. D., \& Wirasasmita, R. H. (2020). WILMO (Web-based Interactive Learning Module), E-learning Design for Vocational School. In Journal of Physics: Conference Series (Vol. 1539, No. 1, p. 012045). IOP Publishing.

Astini, N. K. S. (2020). Pemanfaatan teknologi informasi dalam pembelajaran tingkat sekolah dasar pada masa pandemi covid-19. Lampuhyang, 11(2), 13-25.

Sandiwarno, S. (2016). Perancangan Model E-Learning Berbasis Collaborative Video Conference Learning Guna Mendapatkan Hasil Pembelajaran yang Efektif dan Efisien. Jurnal Ilmiah FIFO, 8(2), 191.

Sugandi, A. I., Bernard, M., \& Linda, L. (2020). Efektivitas Pembelajaran Daring Berbasis Masalah Berbantuan Geogebra terhadap Kemampuan Penalaran Matematis di Era Covid. AKSIOMA: Jurnal Program Studi Pendidikan Matematika, 9(4).

Tafonao, T. (2018). Peranan media pembelajaran dalam meningkatkan minat belajar mahasiswa. Jurnal Komunikasi Pendidikan, 2(2), 103-114. 